第9回エコバランス国際会議 (EcoBalance2010) 報告 (詳細)

南斉 規介・工藤 祐揮・本藤 祐樹・林 清忠・松八重 一代・中島 謙一・村上 進亮· 本下 晶晴・橋本 征二・原 美永子・中嶌 道靖・稲葉 陸太・松野 泰也・篠原 嘉一

\title{
Conference Report on the 9th International Conference on EcoBalance (EcoBalance2010) (Detail report)
}

Keisuke NANSAI, Yuki KUDOH, Hiroki HONDO, Kiyotada HAYASHI, Kazuyo MATSUBAE, Kenichi NAKAJIMA, Shinsuke MURAKAMI, Masaharu MOTOSHITA, Seiji HASHIMOTO, Minako HARA, Michiyasu NAKAJIMA, Rokuta INABA, Yasunari MATSUNO and Yoshikazu SHINOHARA

\section{1.はじめに}

日本LCA学会の主催により、第9回エコバランス国際 会議（以下、EcoBalance2010）が、2010年11月9日から 12 日にかけて東京の日本科学未来館で開催された。共催 はLCA日本フォーラムおよびェコマテリアル・フォーラム、 後援は農林水産省、経済産業省、文部科学省、国土交通省、 環境省、協賛は学協会の 82 団体であった。協賛団体のう ち（独）物質・材料研究機構からは協賛金の支援を受け、 エコバランス国際会議としては初めてスポンサーを募り、 以下の 14 の企業や団体から金銭的支援を頂戴した。

味の素株式会社、株式会社古河テクノマテリアル、株式 会社日立製作所、塩化ビニル環境対策協議会、塩ビ工業・ 環境協会、KPMGあずさサステナビリティ株式会社、み ずほ情報総研株式会社、NPO法人南信州おひさま進歩、 パシフィックコンサルタンッ株式会社、PE INTERNATIONAL、株式会社リサイクルワン、TCO2株式会社、東 洋紡エンジニアリング株式会社、日本ガス協会（順序は講 演要旨集の掲載順と同じ)。

エコバランス国際会議は、1994年以来ライフサイクル アセスメント（LCA）について議論する会議として 2 年ご とに開催され、ライフサイクル思考に基づく持続可能性に
関する評価手法の開発や適用に関する議論をする場として 発展してきた。9回目となる本会議は、日本国政府が国連 で 2020 年に 1990 年比 $25 \%$ の温室効果ガス削減を明言した ことを背景に、10年後にあたる 2020 年を一つの区切りと 考え、会議のメインテーマを“Towards \& Beyond 2020” と設定した。2020年へ向け、さらにその後に向けて、ラ イフサイクル思考を基盤とする研究手法がどのような貢献 ができるか、またすべきかを多面的に議論することを目的 とした。具体的には、エネルギーや鉱物資源、食糧や水資 源の消費、交通、ライフスタイルといった多様な研究分野 で生じている問題を共有し、その解決に向けた議論を通じ て、持続可能な未来を着実に形成するために成すべきこと について、本会議が参加者間の相互理解を深める場となる ことを狙った。

EcoBalance2010にはこれまで同様、大学や学術研究機 関の研究者を初め、政策担当者、企業の専門家やコンサル タントなど国内外から 380 名が参加した。このうち、147 名が以下に示す 28 の国や地域からの海外からの参加者で あり、非 OECD加盟国からは57名の参加があった。

ドイツ（19名）、台湾（16名）、タイ（16名）、韓国（14名）、 アメリカ(14名)、中国 (11名)、オーストラリア (6名)、フィ

南斉 規介(副実行委員長) ・ 中島 謙一・稲葉 陸太/国立環境研究所 $/ \overline{7} 305-8506$ 茨城県つくば市小野川 16-2 工藤＼cjkstart祐揮 (副実行委員長) ・本下 晶晴／産業技術総合研究所／テ 305-8569 茨城県つくば市小野川 16-1

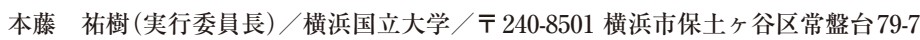
林 清忠 /農業・食品産業技術総合研究機構 / ₹ 305-8666 茨城県つくば市観音台3-1-1 松八重 一代 /東北大学 / $9980-8579$ 仙台市青葉区荒卷字青葉 6-6 村上 進亮・松野 泰也 / 東京大学 / $\% 113-8656$ 東京都文京区本郷 7-3-1 橋本 征二/立命館大学 / $5525-8577$ 滋賀県草津市野路東1-1-1 原美永子／NTT エネルギー環境システム研究所／テ243-0198 神奈川県厚木市森の里若宮 3-1 中嶌 道靖 /関西大学 $/ \bar{T} 564-8680$ 大阪府吹田市山手町 3-3-35

篠原＼cjkstart嘉一／物質材料研究機構／\% 305-0047 茨城県つくば市千現 1-2-1 Keisuke NANSAI(Vice chair) , Kenichi NAKAJIMA, Rokuta INABA / National Institute for Environmental Studies / 16-2 Onogawa, Tsukuba, Ibaraki 305-8506 Yuki KUDOH(Vice chair) , Masaharu MOTOSHITA / National Institute of Advanced Industrial Science and Technology / 16-1 Onogawa, Tsukuba, Ibaraki 305-8569 Hiroki HONDO (Chair) / Yokohama National University / 79-7 Tokiwadai, Hodogaya-ku, Yokohama 240-8501 Kiyotada HAYASHI / National Agriculture and Food Research Organization / 3-1-1, Kannondai, Tsukuba, Ibaraki 305-8666 Kazuyo MATSUBAE / Tohoku University / 6-6, Aoba, Aramaki, Aobaku, Sendai 980-8579 Shinsuke MURAKAMI, Yasunari MATSUNO / University of Tokyo / 7-3-1 Hongo, Bunkyo-ku, Tokyo 113-8656 Seiji HASHIMOTO / Ritsumeikan University / 1-1-1, Norohigashi, Kusatsu, Shiga 525-8577 Minako HARA / NTT Energy and Environment Systems Laboratories / 3-1 Wakamiya, Morinosato, Atsugi, Kanagawa 243-0198 Michiyasu NAKAJIMA / Kansai University / 3-3-35, Yamatemachi, Suita, Osaka 564-8680 Yoshikazu SHINOHARA / National Institute for Materials Science / 1-2-1, Sengen, Tsukuba, Ibaraki 305-0047 
ンランド (5名)、イタリア (5名)、スイス (5名)、フラ ンス (4名)、サウジアラビア (4名)、アラブ首長国連邦 (4 名)、スペイン (3名)、スウェーデン (3名)、カナダ $(2$ 名)、 マレーシア $(2$ 名)、ニュージーランド $(2$ 名)、ノルウェー

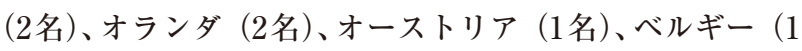
名)、チェコ（1名)、香港（1名)、インド (1名)、インド ネシア (1名)、シンガポール (1名)、イギリス (1名)。

日本国内からの参加者は233名であったが、このうち、 51 名は日本の大学や研究機関に所属する海外からの留学 生や研究者などであり、非 OECD加盟国からの参加者は 24 名を占めた。非 $\mathrm{OECD}$ 加盟国市民の会議への参加費を OECD加盟国市民と比べて大きく割引したこともあったが、 81名（57名 +24 名）もの参加があったことは、これまで のエコバランス国際会議では見られなかった特徵である。

これは、今後もエコバランス国際会議がアジアを中心とし ながらも、ライフサイクル思考を基盤とする世界中の専門 家が参集する会議としてょり一層の役割を果たしていくこ とを示唆するものと考える。

本会議では、2件の基調講演、137件の口頭発表および 112 件のポスター発表が行われた。口頭発表は表 1 に示す ように、8個の特別セッションと 10 個の一般セッションで 構成され、それぞれ 82 件と 55 件の研究発表があった。特
別セッションは、農業・バイオマス資源、都市鉱山、水資 源消費、アジアにおける経済と環境のデカップリング、持 続可能性指標、新技術評価、マテリアルフローコスト会計、 エコマテリアルに焦点を当て、最新の研究成果報告ととも に、今度の課題や研究展望について活発な議論を行った。 本報告では、オープニング、基調講演、特別セッション、 クロージングの概要について紹介する。

\section{2. オープニング}

オープニングではまず、本会議の実行委員長である本藤 祐樹氏（横浜国大）より開会の挨拶が行われた。本藤氏は、 本会議のメインテーマが「Towards and Beyond 2020」 であることを紹介し、持続可能な未来のために、今後 10 年間つまり 2020 年までに私たちは何をすべきかを、いま 決定する必要があることを指摘した。その上で、ひとつの 意思決定は環境や社会経済に負の影響をもたらす可能性が あるが故に、私たちは目の前の利益のみに目を奪われず、 空間的そして時間的に離れたところで生じる間接的な影響 も考慮して、つまり様々なトレードオフを考えたライフサ イクル思考に基づき、意思決定することが重要であると述 ベた。

次に、国際アドバイザリーボードの議長である Matius

表1 セッション別発表件数

\begin{tabular}{|c|c|c|}
\hline セッション分類 & セッションタイトル & 発表件数 \\
\hline 基調講演 & $\begin{array}{l}\text { How should we shape our future? Beyond a low-carbon society（樽床伸二氏） } \\
\text { Chemical risk management considering greenhouse effect（中西準子氏） }\end{array}$ & 2 \\
\hline \multirow[t]{8}{*}{ 特別セッション } & Sustainable management of agricultural and biomass resources using the life cycle approach & 24 \\
\hline & Sustainable mining from natural and urban reserves & 13 \\
\hline & Advances of knowledge for assessing water resource use and consumption in LCA & 4 \\
\hline & Decoupling environmental impact and resource use from economic growth in Asia & 8 \\
\hline & Index and methods to assess socio-economic impacts and sustainability & 5 \\
\hline & International standardization of environmental management accounting & 5 \\
\hline & Applications of LCA to new-technology innovation & 13 \\
\hline & $\begin{array}{l}\text { Materials for raising environmental consciousness of consumers and promoting } \\
\text { environmental practices of consumers }\end{array}$ & 10 \\
\hline \multirow[t]{10}{*}{ 一般セッション } & Theory and practice on supply chain analysis & 4 \\
\hline & Design for sustainable transport & 3 \\
\hline & Life cycle thinking on building & 4 \\
\hline & Resource and environment in Asia & 7 \\
\hline & Lifestyle \& consumption & 4 \\
\hline & International trade \& waste management issue & 4 \\
\hline & Carbon resource management in energy system & 4 \\
\hline & New topics in LCA database & 15 \\
\hline & Environmental education for life cycle thinking & 5 \\
\hline & Risk assessment and management & 5 \\
\hline ポスターセッション & & 112 \\
\hline 合計 & & 251 \\
\hline
\end{tabular}


Finkbeiner氏から挨拶があり、エコバランスに参加する 我々のコミュニティーは、持続可能な未来とは何であるか を事実に基づき理解するための方法論やツールの提供をし ていく必要があり、そのためにも Life-cycle-based suitability assessment methodの発展が重要であると述べた。

続いて、日本LCA 学会の稲葉敦会長が、現在、商品や 企業のカーボンフットプリントが注目を集めているが、学 術的にはこれらは古典的な温室効果ガスのLCAである。 しかし、LCAのコミュニティーは、今こそ、“Real tool for business”としての新しい考え方を提示する時である と述べ、学術的に深化してきたLCAの実社会、とりわけ ビジネスにおける有用性を高めることの重要性に言及した。

\section{3. 基調講演}

\section{1 樽床伸二氏による講演 : How should we shape our future? Beyond a low-carbon society}

衆議院議員である樽床伸二氏が「How should we shape our future? Beyond a low-carbon society」と題して最初 の基調講演を行った。樽床氏は2009年より衆議院環境委 員会の委員長を務めており、2010年 6 月まで委員長として 日本の環境政策を先導してきた。樽床氏は講演の中で次の ように述べた。

気候変動問題は国際社会における最大テーマであり、こ の世界の最大テーマに対応できない国は、遅かれ早かれ衰 退していく。日本が世界の中で名誉ある地位を確立してい くためにも、このテーマにしっかりと取り組む必要がある。 一般に、人が発想を転換するには長い年月を要し、気候変 動が世界最大のテーマになるにも約 20 年を必要とした。

こうした発想の転換のタイムラグは、日本の気候変動に関 する政策決定においても影響を与えてきた。2009年 9 月の 鳩山前首相による国連での $25 \%$ 削減の提言は、発想の転換 を推し進めるにあたり貢献したと理解している。

気候変動問題は 20 年から 50 年という長い期間に渡って 取り組む必要がある課題であるからこそ、気候変動への対 応は経済活動と両立させることが不可欠である。歴史的に 見ても経済の進歩は技術の革新と表裏一体であり、これま では、とりわけ日本では、便利さの追求で技術革新をして きたが、これからは資源の有限性を踏まえたエネルギー分 野の技術革新が重要であり、その社会に与える影響は大き い。そして、日本は世界の排出削減に貢献していくべきで あり、現在、それを推進するための体組み作りに取り組ん でいる。ただし、世界のトップランナー技術でなければ、 海外の排出削減には貢献できない。削減の限界コストが高 い日本で技術を磨くためにも、国内の排出削減努力が必要 である。

また樽床氏は、従来の製造現場にキャップをかける排出
権取引の仕組みではなく、商品のライフサイクルを通じた 排出にキャップをかけるなど、技術革新を妨げない新しい 排出権取引の仕組みの必要性に言及し、枠組み設計や計算 方法などLCAの研究分野に期待するところが大きいと述 べた。最後に、経済と環境を両立させるためには、技術革 新と国内および世界の仕組みを整え、発想の転換をする必 要がある。ライフサイクル思考が世の中に浸透すれば、多 くの人の発想の転換に繋がるのではないかと締めくくった。

\section{2 中西準子氏による講演 : Chemical risk management considering greenhouse effect}

2 目の基調講演は（独）産業技術総合研究所安全科学 研究部門長（当時）の中西準子氏から「Chemical risk management considering greenhouse effect」と題して行 われた。中西氏は、従来より環境政策を適切に立案するに は多種多様な環境リスクを定量し比較することの重要性を 説いており、その研究功績に対して数々の表彰を受けてい る。紫綬摬章、日経BP BizTech Book賞、そして2010年 10月 4 日には、文化勲章を日本政府より授与されている。 中西氏は、講演の中で次のように述べた。

まず、2009年は日本の化学物質リスク管理の元年と言 える。2009年 4 月に化学物質審查法（化審法）が抜本的に 改定され、法律がハザードベースからリスクベースの規制 へと変わり、リスクに基づく化学物質の評価と管理が日本 でも広く実施されることになる。リスクベースの化学物質 リスク規制に切り替えた今、化学物質の管理において重要 なことは、リスクトレードオフを考えることである。リス クトレードオフを考慮しなかった典型的な失敗例として、 DDT (Dichloro-diphenyl-trichloroethane) の使用禁止を 挙げた。しかし、リスクトレードオフを取り扱うためには、 複数のリスクを全て考慮し、異種のリスクを比較すること が必要となる。中西氏は複数のリスクを扱うための原則的 な枠組みとして、コスト、人の健康リスク、生態リスクを 考慮する手法論を約 20 年前より提案してきた。

次に、中西氏は温暖化対策におけるリスクトレードオフ の重要性を冷媒の事例研究を通じて指摘した。例えば、自 動車エアコン用の冷媒を GWPの低さだけをみれば、 $\mathrm{CO}_{2}$ を使用することが良いと判断できるが、その場合、自動車 のライフサイクル $\mathrm{CO}_{2}$ を増加させる。総じて評価すれば、 $\mathrm{GWP}$ は $\mathrm{CO}_{2}$ より高いがR-1234yf $\left(\mathrm{CF}_{3} \mathrm{CF}=\mathrm{CH}_{2}\right)$ の使用が 望ましいと考えられる。もう1つの例として、ルームエア コン用の冷媒の事例を紹介し、リスク管理においては、常 にリスク削減量が最大になる代替物を選択するだけでは不 十分であることを説明した。そして、個別のリスクを $\mathrm{de}$ minimis risk程度に抑え、かつ、条約等によって求められ る削減量の約束を履行できる範囲で、代替策の費用対効果 
が高いものを選ぶべきと主張した。最後に結論として、以 下の5 項目を再確認し、de minimis riskという概念の有効 性を提示して基調講演を終えた。

[1] リスクの総和を推算する。

[2] 総リスク削減量が最大になる代替物を選ぶ。

［3］しかし、総リスク削減量のみを考えるだけでは不十 分であり、他のいくつかの条件を考虑する。

［4］代替に伴うリスク削隇の費用対効果と外的要請を考 虑する。

［5］ある地域やある個人にふりかかる個別のリスクにつ いても十分な注意をする。

\section{4. 特別セッション}

先にも紹介したように、口頭発表は8個の特別セッショ ンと 10 個の一般セッションで構成された。以下に特別セッ ションの内容について概要を記す。

\section{1 特別セッション1: Sustainable management of agri-} cultural and biomass resources using the life cycle approach (ライフサイクルアプローチによる持続可能 な農業・バイオマス資源管理）

持続可能な農業・バイオマス資源の生産と利用は、将来 の人間の食料消費とエネルギー・素材用の化石燃料使用量 の削減に向けて重要な問題であると認識されており、食 料・エネルギー・素材用としての資源の生産と利用に加え、 土地利用、土地利用変化抒よび林業（LULUCF）による 環境影響や、肥料用としての天然資源の枯渴についても分 析を加える必要がある。この特別セッションでは、持続可 能な農業と食料、バイオエネルギーの生産と利用、バイオ リファイナリー、農工コンプレックス、農業残渣・廃棄物 の利活用、LULUCFによる炭素放出と蓄積、生態系サー ビスと生物多様性、無機養分の MFA/SFA、省資源技術 の開発など、ライフサイクル思考に基づく持続可能な農 業・バイオマス資源管理に向けた様々な評価手法・結果扔 よび問題点を議論した。セッションオーガナイザーは工藤 鿆揮（産業技術総合研究所）、林清忠（農業・食品産業技 術総合研究機構)、松八重一代 (東北大学) が務め、6つ のセッションで世界 9 カ国から、8件の招待講演を含む 24 件の発表が行われた。

8 件の招待講演の概要は、以下の通りである。

Roland W. SCHOLZ氏（ETH Zurich）は、attributional LCA と consequential LCA の違いについて統一的な 見方を説明し、どちらのアプローチが選択されるかによっ て、環境影響評価の結果には大きな違いがもたらされるこ とを示した。その上で、スウェーデンでのバイオエタノー ル増産の事例、すなわち 2020 年までに脱石油社会を構築
するという国家戦略に基づいて決定されたバイオエタノー ルの増産に関する事例を分析した。

Bastian WITTSTOCK氏（University of Stuttgart）は、 土地利用の影響評価を行うために開発されたツールである LANCA (Land Use Indicator Calculation Tool) の概要を 説明した後、日本におけるバイオマス利用システムへの適 用事例（6事例）を報告した。その中で、このアプローチ の有用性、デー夕収集に関するガイドラインの重要性を示 した。

Lise LAURIN氏（EarthShift, LLC) は、トータルコス トアセスメント（TCA）によって、バイオ燃料生産への 投資に関するコストとベネフィットを分析した。とりわけ、 投資プロジェクトの持続可能性を評価するとともに、投資 の不確実性を将来獲得されるであろう収益のレンジ（best, probable, worst）によって示した。

Rolf FRISCHKNECHT氏（ESU-services Ltd.）は、日 本版エコロジカル・スケアシティ手法の開発に関する報告 を行った。この手法は、スイスのエコファクター手法の最 新版（2006年版）に基づいている。同手法を日本に扔け るエネルギー作物栽培の評価に適用し、栽培法の技術改善 により、環境負荷をどの程度低減できるかを示すことがで きた。

Evan M. GRIFFING氏 (Environmental Clarity, LLC) は、 デザインベースの方法論を用いて作成した主要な化学肥料 のライフサイクルインベントリに関する報告を行った。対 象とした肥料は、塩化アンモニウム、硫酸アンモニウム、 リン酸アンモニウム、過リン酸石灰、塩化カリウムである。 また、ecoinventとの比較により、方法論の妥当性、イン ベントリデータの特徵を検討した。

David A. VACCARI氏 (Stevens Institute of Technology）は、世界におけるリンの需給状況について報告を行い、 統計モデルを用いた解析によりリン鉱石供給のピーク予測 を行った。

大竹久夫氏 (大阪大学) は廃棄物からのリンの回収技術 について報告を行った。排水污泥ならびに焼却灰はリンの 回収において大きなポテンシャルを持って扔り、我が国に おける持続的なリン資源管理において重要な地位を占めて いることを指摘した。また我が国において産官学連携でリ ンリサイクルを推進するリン資源リサイクル推進協議会の 活動についての紹介もあわせて行われた。

Shabbir H. Gheewala氏 (King Mongkut's Univ. of Technology Thonburi) は、ライフサイクルアプローチを 用いたバイオマスのエネルギーと環境分析の研究成果（サ トウキビ、パーム油、ジャトロファ）を紹介し、持続的な バイオマス資源管理のためには副産物の有効利用が重要で あることを指摘した。また様々なライフサイクルステージ 
のトレードオフを捉えるためには、燃料、電力の生産に加 充、バイオマスから生産される付加価值のある化学製品を 生物変換プロセスに統合する、いわゆる「バイオリファイ ナリー」のライフサイクルアセスメントが必須であると結 んだ。

\section{2 特別セッション 2 : Sustainable mining from natural and urban reserves（持続可能な資源利用 〜鉱山と 都市鉱山 )}

本特別セッションでは、「持続可能な資源管理」のあり 方を考える事を目的として、3つのセッションにまたがって、 3 件の招待講演を含めた 12 件の発表が行われた。3つのセッ ションを通じて、会場は盛況であり、資源経済学、材料科 学、環境科学、物質フロー分析 (MFA/SFA)、LCA といっ た幅広い知見に基づいた議論が行われた。

第1セッションでは、馬鴻文氏（国立台湾大学）による 招待講演を含めて、アジア地域に扔ける亜鉛とカドミウム を対象としたMFA/SFAに関する研究発表が4件行われた。 馬氏は、台湾における製鋼業㧍よび電気师ダストの発生状 況について紹介した。また、MFA/SFA手法により鉄資 源循環に随伴する带鉛フローを明らかにすると共に、带鉛 原料の供給源としての電気炉ダストの可能性と Waelzプロ セス等の中間処理プロセスの重要性を示した。

第2セッションでは、中村崇氏 (東北大学) による招待 講演を含めて、3件の発表・報告が行われた。中村氏は、 環境管理の視点から鉛製錬におけるブラウン管 (CRT) ガ ラスのリサイクルについて紹介した。CRTガラスのリサ イクルに扔いては、再度 CRTガラスとして水平リサイク ルする事が容易であるが、近年は、日本国内に扔けるCRT テレビが製造中止になると共に、他アジア地域における CRTガラスの需要も減少しつつある。この問題を受けて、 1つの解決策として、鉛製錬におけるCRTガラスの利用の 可能性が示された。討論において、会場から欧州における CRTリサイクルの現状についてのコメントがあった。また、 霜鳥洋氏（(独）石油天然ガス・金属鉱物機構、JOGMEC) から、JOGMECによる鉱山における鉱害防止の取り組み についての紹介が行われた。現在、世界中の鉱山業界で酸 性坑排水（AMD: Acid Mine Drainage）の処理が問題に なっているが、我が国に扔いても例外ではない。むしろ、 我が国に扔いてはほぼ全ての鉱山が休止、ないしは閉山さ れており、その処理を担当すべき企業が既に倒産している 場合なども多く、政府が対応を余儀なくされている。

第3セッションでは、Sangwon Suh氏（University of California in Santa Barbara）による招待講演を含めて、 5 件の研究発表が行われた。Suh氏は、産業間の金属の物質 フローを把握・解析するための手法として、ハイブリッド
型産業連関表に基づくGoshian モデルの有用性と韓国経済 への応用についての報告が行われた。鉛、亜鉛、マンガン、 アルミニウム、モリブデンの5つの金属についての解析結 果が紹介された。この他、竹田修氏（東北大学）から、治 金学的な観点から、熱力学解析モデルを用いた金属の回収 可能性・不純物の除去可能性についての報告などがあり、 資源利用・資源管理に関する広い議論が行われた。

\section{3 特別セッション3: Advances of knowledge for as- sessing water resource use and consumption in LCA (LCAにおける水資源と消費に関わる評価)}

人間生活にとって水資源はその他の資源と同様に必要不 可欠な資源である。水は基本的に再生可能資源として捉え られ、これまでのLCAでは水資源の利用・消費に関する 評価について十分な議論がなされていない。しかしながら、 世界に扔ける人口増加や経済発展に伴う水需要の増加が予 測されていることから、LCAにおいてもウォーターフッ トプリントのように水資源の利用・消費に関わる評価に注 目が集まってきている。そこで、LCAに打いて水資源の 利用・消費に関わる先進的な知見を共有し、今後の望まし い研究課題や方向性について議論することを目的として本 特別セッションが企画された。非常に関心が高まっている トピックであり、全7件の口頭発表（4件のポスター発表 のショートプレゼンテーション含む) が行われ、会場にも 多くの聴衆が集まっていた。

本特別セッションの招待講演者であるAnnette KOEHLER氏（ETH Zurich）から水利用・消費に関わる インベントリ分析およびインパクト評価に関する手法開発 の動向、ならびに開発された手法間のギャップに関する指 摘や適用可能性について紹介された。同氏によると、イン ベントリ分析やインパクト評価のための指標や手法が既に いくつか開発されているが、これまでのインベントリ分析 で得られる情報とインパクト評価に必要な情報にはギャッ プがある。水資源の利用・消費に関わる影響を評価するた めには投入水量だけでは情報として不十分であり、使用の 状況 (利用/消費 / 枯渴)、水源の種類、水源户排出先の地 理的情報が影響評価のためには必要となる。こうした必要 な情報のギャップとインベントリデー夕を収集する際の負 担とのバランスをうまく均衡させたインベントリ分析・イ ンパクト評価のための指標や手法の開発が必要であると指 摘された。

インベントリ分析におけるッール開発の動向としては、 産業連関分析法に基づいたウォーターフットプリントのた めのデータベース開発について、Jing LIU氏 (早稲田大学) からは中国を対象とした事例、小野雄也氏 (東京都市大学) からは日本を対象とした事例の紹介があった。インパクト 
評価手法の開発事例として、本下晶晴氏（(独）産業技術 総合研究所）からは農業用水の不足に伴う健康被害評価手 法について、Francesca Verones氏（ETH Zurich）から はペルーに扔ける牛乳生産に起因する陸生生態系への影響 評価について報告された。適用事例の紹介としては、 Ramon FARRENY氏 (Univ. Autònoma of Barcelona) から地中海地域における雨水利用システムの評価事例につ いて、Young Deuk KIM氏 (Rural Research Institute of KRC) からは灌溉施設の評価事例についての発表があった。

LCAにおける水資源の利用・消費に関わる影響評価の ための様々な手法が開発されつつあるが、水利用形態、水 源や利用地域によってその影響が異なることを認識する必 要がある。本セッションを通じて、インベントリ分析の指 標・手法とインパクト評洒手法に必要な情報のギャップな ど、異なる手法間での整合性を確保する必要があることが 今後の課題として認識された。

4.4 特別セッション4: Decoupling environmental impact and resource use from economic growth in Asia（アジアの経済成長と環境影響および資源消費と のデカップリング)

アジアでは経済の急速な経済成長に伴い、資源消費と温 室効果ガス排出量の増加が顕著になっている。また、大気 污染、水質污染、土滾污染、廃裹物といった従来の環境問 題も深刻化している地域も存在する。国立環境研究所の南 斉規介氏と橋本征二氏が企画した本特別セッションは、今 後もアジア経済を成長させながら、上記の環境問題や資源 の大量消費を抑制する、すなわちデカップリングに向けた 方法論や実際の取り組みについて議論することを目的とし、 次の研究報告が行われた。

まず、国立環境研究所の赤木純子氏から「アジアにおけ るGHGインベントリ整備に関するワークショップ」に参 加する12のアジアの国々のGHG排出および吸収量について、 現状の推計結果と精度に関する問題点について報告があり、 農業部門とLULUCF (Land-Use and Land-Use Change and Forestry）部門の推計方法の改良が重要と示唆された。

本セッションでは、中国のエネルギー研究所からJiang Kejun氏を招待講演者として招いた。Jiang氏は、IPACモ デル群による中国の中長期的な経済成長とエネルギー消費 量およびGHG排出量のシナリオに基づく予測結果を報告 した。2030年を中国の GHG排出量のピークとするにはエ ネルギー転換技術、再生可能エネルギー、原子力エネル ギーの導入など技術的政策に加え、炭素税、排出権取引等 の制度的政策の必要性を示唆した。また、中国の低炭素化 にとって重要となる新エネルギー技術の中には、中国以外 での技術開発の進展に委ねるものもあるが、IGCC (Inte- grated coal Gasification Combined Cycle) などのクリー ン石炭技術の開発についは、中国国内の潜在的需要も多く 見込まれる。そのため、こうした分野に対する研究開発の 重要性を訴え、中国が環境技術で世界の主導的立場になれ ば、経済と環境の両面で中国に大きな利益となると結論付 けた。

次に、国立台湾大学のChia-Wei CHAO 氏は、ハイブ リッド多地域間ライフサイクルアセスメント法（HMRLCA）を用いて、台湾の産業活動とエネルギー構造の変 化を考慮し、2020年における潜在的な環境負荷量を推計 した。その結果、台湾の「低炭素成長政策」に関連する政 策目標に基づいて、経済、産業活動および技術的なシナリ オを設定し、輸出入による影響も考虑した結果、2020年 にはGHGだけでなく健康影響や水資源消費などの他の影 響も增大する可能性を示唆した。

アジアリニューアブルズの William II Young BYUN 氏 からバイオマスなどの再生可能エネルギー資源は、従来の 石炭火力のような大規模に中心的拠点に設置するトップダ ウン型の導入ではなく、地域経済を活性化し、環境面でも 負荷が低い導入方法がアジアの経済と環境のデカップリン グには必要だとの報告が具体的事例を交えてあった。

豪国CSIROの Heinz SCHANDL 氏は、アジア太平洋地 域の物質利用量と資源生産性について報告した。各地域の 1970 年から 2005 年までの資源消費の変化を解析し、IPAT 法に基づき 2030 年および 2050 年における資源消費と資源 生産性に関してシナリオ分析を行った。 $\mathrm{I}=\mathrm{P} \times \mathrm{A} \times \mathrm{T}$ は、 $\mathrm{I}=\mathrm{DMC}, \mathrm{P}=$ Population, $\mathrm{A}=\mathrm{GDP} /$ Capita, $\mathrm{T}=\mathrm{DMC} /$ GDP と定義し、これまでのIにはAの寄与が大きいことを 明らかにし、貧困の克服と物質消費の削減の同時達成の難 しさに言及した。また、将来シナリオでは完全雇用を確保 する場合、物質利用の効率性を高めるだけでは、アジア太 平洋地域の物質消費の低減の見达みは限定的であることを 示した。

国立台北大学の Guan-Lin LU 氏は、台湾経済のEconomy-wide MFAの結果と資源生産性に関連する指標を計 測した。DMI (Direct Material Input) は2006年まで増加 したが、2007年以降、世界的な経済不況の影響により減 少に転じたことを示し、GDP/DMI、DPO (Domestic Processed Output) /GDP、per capita DMI、per capita DPO, per capita GDPを1987年から 2008年までの経年変 化を考察し、輸出を中心とする台湾経済の特徵に言及した。

Chulalongkorn 大学のSuthira Puangsiri 氏は、夕イの 自治体が導入する「都市ごみ預金システム」の効果をリサ イクル量と環境負荷量の変化に着目して分析した。都市ご 久預金システムでは、地域の人々は銀行に廃棄物口座を開 設し、リサイクル可能な廃裹物を地域の廃裹物収集セン 
ターに売却することによる収益を預金する。このシステム の導入により、最終処分量と環境負荷の低減のみならず、 市民のごみ処理の行動を変え、更には廃裹に関してより強 い関心と責任感を生むという新しい文化の形成にも貢献し たと報告した。

最後に、南斉規介氏がGLIO (Global link input-output model）により日本が国内外に誘発するGHG排出量の定 量結果を報告した。加工度の異なる日本の商品について、 グローバルな GHG 誘発構造を解析し、国際貿易のネット ワークに着目した排出構造の視覚化を行った。商品毎に大 きく異なる $\mathrm{GHG}$ 誘発構造が存在することを同定し、今後 の商品需要変化の適切な見通しが、国内外の効率的な GHG削減において重要であると指摘した。

4.5 特別セッション 5 : Index and methods to assess socio-economic impacts and sustainability (社会 • 経済影響およびサステナイビリティ評価のための指 標と手法)

LCA は製品およびサービスの環境影響を定量化するた めの共通手法としてすでに標準化され、実用化されている。 しかしながら、実際にサステイナブルな生産および消費を 行うためには、環境だけでなく、経済や社会といった側面 を含めた多くの視点を考慮する必要がある。今後 10 年間に、 ライフサイクルアプローチを利用した社会影響評価、社会 経済分析、サステイナビリテイ評価はますます重要な役割 を担うことが期待されている。本特別セッションオーガナ イザーは本藤祐樹氏（横浜国立大学）、原美永子氏（NTT 環境エネルギー研究所）が務め、技術、製品およびサービ スの社会・経済評価手法および指標開発、適用について論 議するためのプラットホームを提供することを目指した。

本セッションでは6件の発表が行われた。招待講演者で ある Matthias FINKBEINER氏（T U Berlin）は「ライフ サイクルサステイナビリティ評価〜 LCAの社会的・経済 的側面の統合」と題した基調講演を行い、サステイナビリ ティ指標開発の国際的な背景について振り返り、環境およ び社会経済影響を考慮した新たなサステイナビリテイ指標 であるライフサイクルサステイナビリティダッシュボード （LCSD）の概要を説明した。Guido SONNEMANN氏 (UNEP DTIE) はUNEPのソーシャルLCAについて、ラ イフサイクルイニシアティヴにおける資源マネジメントの ための評価ツールの開発活動について紹介した。高橋和枝 氏（NTT）は、社会影響の貨幣価值指標であるGross Social Feel-good Index (GSF) について紹介し、日本とフ ランスでのテレビ会議の評価結果を比較分析した。 Johanna Elisa LAAKSONEN氏（Aalto University）は、 フィンランドのデパートにおけるサプライチェーン管理の
意思決定ツール開発に関する概要を説明した。江口里佳氏 (慶應大学) は、建物への断熱材の利用による居住者の健 康と社会的な福利厚生への経済的な利点について、アン ケートに基づく定量的な評価結果を報告した。

社会・経済影響評価に関して関心が高まりつつあり、環 境と社会・経済とを適切につなげるためには、実用的な評 価ツールと手法論の双方が求められている。社会影響評価 では、評価方法に関する合意を形成するための標準化など の「トップダウン型」アプローチとともに、今回発表され たケーススタディのような「ボトムアップ型」アプローチ が必須であると総括された。

\section{6 特別セッション 6 : International standardization of} environmental management accounting（環境管理 会計の国際標準化)

マテリアルフローコスト会計（MFCA）は、世界的に 認められた有用性の高い環境管理会計手法である。2007 年から、MFCAの一般的な枠組みを国際的に標準化しよ うとする作業が進められており、2011年度にはISO14000 ファミリーのISO14051として発行される予定である。こ のような国際標準化の動向を踏まえて、サステイナビリ ティを達成するための MFCAの可能性を議論することが 本特別セッションの目的であった。このセッションでは、 MFCAのISO化によってサステイナブルマネジメントが 実現される実務的かつ理論的な可能性に関する発表と、 MFCAの企業事例やMFCAの高度化研究に関する発表が 行われた。なお、このセッションは、ISO14051発行作業 における日本代表エキスパートである中嶌道靖氏（関西大 学)によって企画された。

本セッションでの招聘講演者である Bernd WAGNER氏 (University of Augsburg, Germany) はMFCAの考案者で、 ISO14051発行作業におけるドイツエキスパートの1人でも あり、今回、「2020年に向けての挑戦における MFCAの役 割」(The Role of MFCA in Coping with the Challenges of 2020）という論題で講演した。この講演の中で同氏は、 トリプルボトムライン（経済・社会・環境）での業績を達 成するMFCAの可能性と役割を強調した。また、特に「世 界的なレベルで人工的なマテリアルフローを支配すること は、地球上に人類が存在する上で不可欠である。MFCAは、 マテリアルフローをコントロールし、国際的なレベルでの 持続可能性に対する人類の経済・環境・社会での影響を支 配して、コントロールするためのツールである。今日、我々 はまだ経済成長を基礎としたマテリアルと対峙するような マテリアルの環境と社会の影響を世界的に制限するには 至っていない。しかしながら、我々は待つことは出来ない。 我々は、ミクロ経済における企業レベルから、トリプルボ 
トムラインという観点でのマテリアルフローのコントロー ルに着手することができる。このことによって、個々の企 業の長期的な生き残りとサステイナビリティが、グローバ ルなマテリアルの統治に向けた発展に寄与することができ る。我々は我々の未来を予測することができない、しかし、 未来にそれが可能であるかないかの条件を我々が今、確認 することはできる。ということが、この特別セッション で重要な点だと語った。

この特別セッションの他の $4 つ の$ 発表は、古川芳邦氏 (日 東電工）・立川博巳氏（プロファームジャパン）による 「ISO14051の国際標準化の経過とその内容（The international standardization process and contents of ISO14051)」、沼田雅史氏（積水化学工業）による「積水 化学工業グループにおける資源生産性向上のためのMFCA 企業マネジメント (Case study of corporate management by MFCA to promote material efficiency on the whole of group companies in SEKISUI Chemical) 」原田聖明氏 (オ ムロン）による「オムロンにおける MFCAによる生産マ ネジメントとサプライチェーンマネジメント (Case study of manufacturing management by MFCA, including supply chain management in OMRON)」、最後に、中嶌 道靖氏・木村麻子氏（関西大学）による「企業の内部情報 と外部情報の両側面に活用できるMFCAによるサステイ ナブルマネジメント情報 (Modeling of sustainable management information by MFCA to use as internal and external corporate information)」であった。

MFCA は日本ではプロセス、特に工場での生産プロセ スでの資源生産性向上に活用されてきた。しかしながら、

MFCA はビジネスプロセスにおいて MFCA マネジメント の範囲と規模を自立的に拡張しようとする傾向がある。積 水化学工業での事例では、ビジネスプロセスでの廃裹物と ロスを削減し、企業のサステイナブルマネジメントのひと つの業績評価として MFCAによる削減成果を評価し、企 業グループ全体のPDCA (plan-do-check-act) サイクルに よるマネジメントを構築している。企業マネジメント手法 としてMFCAが活用されている事例である。続く、オム ロンの事例では、まず製造プロセスでの資源生産性の見え る化手法としてMFCAを導入し、さらにマテリアルロス の発生原因を明らかにするために MFCA 分析をサプライ チェーンに拡張している。オムロンとサプライヤーとのサ プライチェーンでの親密なコミュニケーションによってマ テリアルロスの削減活動を共同で実施している。

これらの事例は典型的なエコイノベーション（ecoinnovation）と呼ぶことができるであろう。ISO14051が 発行されれば、このようなエコイノベーションがビジネス プロセスでより促進されると考えられる。MFCAの新し
い機能や有用性を開発・発展させることで、MFCAによ るエコバランスやサステイナビリティ（EcoBalance and Sustainability）が達成されるようにすることが重要であ ろう。そして、MFCAの成果はグローバル社会における サステイナビリティのひとつの指標になるであろう。資源 生産性という観点から、MFCAはグローバル市場の製品 とサービスに関するビジネスプロセスの優先順位を明示す ることが出来るようになるであろう。

今回の特別セッションでの討論において、資源生産性情 報をどのようにして社会に提示し、その情報をどのように 活用すればいいのか、また企業の外部情報として利用する 場合にはどのような内容が必要となるのかを検討すること が、将来の課題として挙げられた。また具体的には、 ISO14051が発行され世界でMFCA 的な思考が普及した場 合に、MFCA 情報を効果的に活用してサステイナブルマ ネジメントを構築するための戦略が必要であると話し合わ れた。最後に、次回のエコバランス国際会議において、改 めてこの議題に関して討論する機会を持つことを約束して 終了した。

\section{7 特別セッション7: Applications of LCA to new- technology innovation (環境関連技術革新への LCA の適用)}

本特別セッションの大きなテーマは「環境関連技術革新 へのLCAの適用」である。13件の研究発表が選ばれ、大 きく分けて 3 部構成となった。本特別セッションの担当は、 稲葉陸太氏（国立環境研究所）と松野泰也氏（東京大学） である。

第 1 部では、バイオマス利用に関する研究が 3 件報告さ れた。具体的には、日本の自治体におけるバイオマスタウ ン構想の傾向分析、ノルウェーの森林産業シナリオの比較 評価、そしてドイッの森林産業の複合システムのモデル分 析である。質疑応答では、技術システムに関連する社会経 済的な要素が重要課題の1つとして抽出・議論された。

第 2 部では、新素材や新技術に関する研究が 6 件報告さ れた。それらの題目は、情報通信技術（ICT）の事例研究 による生産システム評価、インターネット会議手法におけ る環境性能の比較、カーボン・ナノチューブ（CNT）複 合素材の影響評価、炭素固定・貯蔵技術 (CCS) の環境影 響の比較、廃電気電子機器（WEEE）のマテリアルフロー と価值の分析、および水素を基盤とする交通を事例とした 技術革新に向けた複合LCAの提案である。このまとまり での重要課題は、システムを比較するときの機能単位の設 定、データの不確実性によって結果に幅が出た場合の解釈、 複数の影響項目に対する包括的な評価手法、およびマテリ アルフローの変動要因である。 
第3部では、主に電気自動車 $(\mathrm{EV})$ と関連技術システ ムにLCAを適用した研究が 4 件報告された。 EVは、日本 においても2010年に商業生産が始まるなど、関心と話題 を集めている。本セッションでは、海外の事例としてル ノー社から、日本の事例として日産自動車と産業技術総合 研究所から、EVのLCAについて報告がなされた。加えて、 $\mathrm{EV}$ 導入がアルミのマテリアルフローに及ぼす影響の分 析が東京大学から報告された。EVのLCAでは、環境負荷 が高いリチウムイオン電池の再使用もしくは共有によって 環境負荷が削減できることが報告された。加えて、EVの 1 回充電による最長走行距離は、電池容量によって異なる。 一般に、電池容量が小さければ、最長走行距離は短くなる が、車体軽量化で環境負荷は小さくなる。内燃機関自動車 に対する従来のLCAでは、機能単位を「10・15モードで の 10 年間 10 万 $\mathrm{km}$ 走行」と定義してきた。しかし、EVに 関して、1回充電による最高走行距離を考慮せず、走行年 数と生涯走行距離で単純に機能単位を決めて良いか、議論 が分かれるところである。この点に関しては引き続き議論 が必要である。

\section{8 特別セッション 8 : Materials for raising environmen-} tal consciousness of consumers and promoting environmental practices of consumers（消費者の環 境意識を高めて環境行動に繋がる素材)

エコマテリアルとは、製品性能をライフサイクル環境負 荷で割ることによって定義される製品の環境効率を高める 材料である。すなわち、製品性能を向上させるか、ライフ サイクル環境負荷を減少させる材料をエコマテリアルと呼 ぶ。エコマテリアルの開発は、これまで製品の環境効率を 向上させることに貢献してきた。しかし、環境効率の高い 製品（エコプロダクッ）が普及してきたにも関わらず、日 本の民生部門からの GHG排出量は増加してきている。こ の状況が意味するのは、GHG排出量のコントロールはエ コプロダクツの普及だけでなく、それを利用する側が大事 であるということである。この特別セッションでは、エコ マテリアルの新しい側面、すなわち製品を造る側からだけ でなく利用する側から観たエコマテリアルについても議論 がおこなわれた。口頭発表は全部で 10 件で、篠原氏によ る開会講演に続いて、Zhang氏（中国）および梅澤氏（日 本)、さらにはBenedetti氏（イタリア）の招待講演があっ た。一般講演として、日本からは阿部氏、橋本氏、古屋氏 および醍醐氏がエコマテリアルの新しい観点について、夕 イからはMungkalasiri氏が買い物袋に関する興味深い調 査結果、イギリスからはDimitrokali氏が建築産業をエコ に導くための方法が発表された。本セッションを通して、 材料を作る側、製品を作る側およびそれらを利用する側
（市民）の間の情報伝達が、エコマテリアルの新しい側面 において鍵を握ることが確認された。

\section{5. クロージング}

クロージングでは、112件のポスター発表の中から選ば れたエコバランス国際会議ポスター賞の受賞者が発表され た。ポスター賞は 1 次審査による候補者の選定と 2 次審査 による投票結果に基づき、Gold poster award (金賞)、Silver poster award (銀賞)、Bronze poster award (銅賞) の 3つの賞を選考した。

ポスター賞の選考は、まず第1次審査として実行委員会 委員による講演要旨の查読を行い、第 2 次審査へ進むポス ター賞候補（8件）を選定した。講演要旨の查読は講演要 旨から著者名、所属、連絡先、参考文献を全て削除する夕゙ ブルブラインド方式により行われた。第 2 次審査は、11月 12 日に行われたポスターセッション中に実施され、24名 のポスター賞審査員が総合的見地から各候補者を評価した。

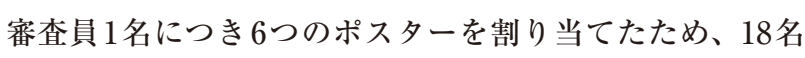
の審査員が1つのポスター賞候補を審査した。

第2次審査には、国際アドバイザリーボードから 9 名、 海外の招待講演者やセッション座長等から11名、日本 LCA 学会理事から4名の方々にご協力をいただいた。以下 の審査員に心より感謝申し上げる。

Prof. Bruno De BENEDETTI, Dr. Marc-Andree WOLF, Mr. Mark J. GOEDKOOP, Dr.Martin BAITZ, Dr. Rolf FRISCHKNECHT, Prof. Yuh-Ming LEE, Dr. Annette KOEHLER, Prof. Sangwon SUH, Prof. Shabbir H. GHEEWALA、Dr. Lise LAURIN, Mr. Bastian WITTSTOCK, Dr. Evan GRIFFING, Prof. David A. VACCARI, Prof. Hwong-wen MA, Prof. Kejun JIANG, Prof. Di ZHANG, Dr. Andreas CIROTH, Dr. Witold-Roger POGANIETZ, Dr. Heinz SCHANDL, Dr. Jan Minx, Prof. Hirokazu KATO, Dr. Atsushi TERAZONO, Prof. Yasushi KONDO and Prof. Yasushi UMEDA

Gold Poster Awardの受賞者には、賞状と賞金、そして 記念の盾が日本LCA学会副会長の森口祐一氏から贈呈さ れた。また、Silver Poster AwardとBronze Poster Awardの受賞者には、賞状と賞金が授与された。受賞者 は以下の通りである。

\section{Gold Poster Award}

Miyata, N., Kikuchi, Y., Hirao, M. (2010): Scenario Analysis on Pulp and Paper Flow for the Design of Paper Recycling System, Proceedings of The 9th International Conference on EcoBalance, P-106 (in CD-ROM), Tokyo, Japan. 


\section{Sliver Poster Award}

Yamanari, M., Adachi, K., Dowaki, K., Sadamichi, Y. (2010): A System Analysis of Bio-ethanol Produced from Cassava and Sugarcane in Northern Thailand, Proceedings of The 9th International Conference on EcoBalance, P-073 (in CD-ROM), Tokyo, Japan.

\section{Bronze Poster Award}

Goto, Y., Kagawa, S., Kudoh, Y., Nansai, K. (2010): Structural Decomposition Analysis of the Automobile Gasoline Consumption and the Sensitivity Analysis, Proceedings of The 9th International Conference on EcoBalance, P-114 (in CD-ROM), Tokyo, Japan.

クロージングの最後に、本会議の実行委員長である本藤 氏より閉会の挨拶が行われた。本藤氏は、本会議における 議論、そして本会議で形成された新しいネットワークが、 参加者の今後の研究活動やビジネスに生きることを確信し ていると述べた。そして開会の挨拶でも述べたように、持 続可能な未来のためには、広く様々なトレードオフを考慮 して意思決定がなされること、すなわちライフサイクル思 考に基づく意思決定が不可欠であることを強調して会議を 締めくくった。 